\title{
A Burning Story: The Role of Fire in the History of Life
}

\author{
JULI G. PAUSAS AND JON E. KEELEY
}

\begin{abstract}
Ecologists, biogeographers, and paleobotanists have long thought that climate and soils controlled the distribution of ecosystems, with the role of fire getting only limited appreciation. Here we review evidence from different disciplines demonstrating that wildfire appeared concomitant with the origin of terrestrial plants and played an important role throughout the history of life. The importance of fire has waxed and waned in association with changes in climate and paleoatmospheric conditions. Well before the emergence of humans on Earth, fire played a key role in the origins of plant adaptations as well as in the distribution of ecosystems. Humans initiated a new stage in ecosystem fire, using it to make the Earth more suited to their lifestyle. However, as human populations have expanded their use of fire, their actions have come to dominate some ecosystems and change natural processes in ways that threaten the sustainability of some landscapes.
\end{abstract}

Keywords: fire regime, fire history, fire ecology, plant evolution, human evolution

$\mathbf{F}$ ire is a widespread process in the earth system and plays a key role in ecosystem composition and distribution (Bond et al. 2005). This novel perspective contrasts with the classical view that plant and animal distributions can be explained solely by climate and soil. Ecologists, biogeographers, and paleobotanists have long ignored fire as a key ecosystem process; its importance is now being revealed more than ever by attempts to model global vegetation change (Bond and Keeley 2005). Although numerous case studies of the impacts of fire in contemporary ecosystems have been made, few have attempted to view the evolutionary importance of fire throughout Earth's history or to place fire history within the context of humans and the appearance of human societies. We present a historical perspective, from the origin of land plants to the present, that explores the multitude of roles fire has played on Earth and the ways in which humans have affected those roles. Our general hypotheses are that (a) the world cannot be understood without considering fire, because fire has strong ecological and evolutionary consequences for biota, including humans; and (b) since the rise of humans, people have heavily influenced fire regimes, often in ways that greatly affect the sustainability of some ecosystems. To demonstrate these points, we first review early evidence of fire since the origin of land plants, and then we review how fire and humans have interacted in the preindustrial era and in the modern world. We conclude with remarks on the role of fire in the near future.

\section{The prehuman era: Early evidence of fire}

The origin of fire is tied to the origin of plants, which are responsible for two of the three elements essential to the existence of fire: oxygen and fuel. The third element, a heat source (figure 1a), has probably been available throughout the history of the planet (mainly through lightning, but less predictably from volcanoes and sparks from rock falls or meteorite impacts). Before the appearance of photosynthetic organisms, the atmosphere lacked sufficient oxygen, and before the appearance of terrestrial plants, it lacked fuels; thus, fire did not exist on our planet. By the beginning of the Paleozoic Era (540 million years ago [mya]; figure 2) the oxygenated atmosphere was sufficient to support fire, but the lack of terrestrial plant fuels limited the possibility of fire. However, with the earliest Silurian origins of land plants, there is evidence of fire. Glasspool and colleagues (2004) reported charred remains of low-growing vegetation of the earliest stomata-bearing plants (440 mya), plus charred coprolites, indicating a low-temperature surface fire.

The subsequent fire history on Earth is marked by periods of apparently high and low activity, which seem to be tied to changes in atmospheric oxygen levels (Scott and Glasspool 2006). There is clear evidence of charcoal in the Devonian deposits (400 mya; Scott 2000, Glasspool et al. 2006), although extensive charcoal deposits do not appear until the late Paleozoic Era (345 mya; Falcon-Lang 2000, Scott 2000), concomitant with a rapid rise in atmospheric oxygen from the 
a

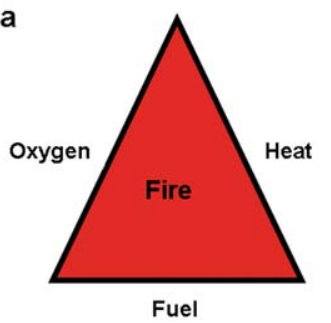

b

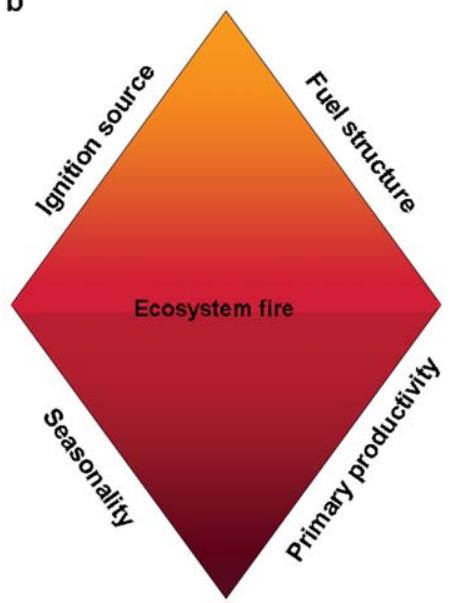

Figure 1. Schematic of factors for (a) the physical process of fire and (b) fire as an ecosystem process. Sufficient primary productivity is needed to spread fire, but climatic seasonality is required to convert these potential fuels to available fuels; however, seasonality could be manifested as annual to decadal cycles of drying conditions. Fire regimes will be controlled strongly by ignition frequency and fuel structure.

\begin{tabular}{|c|c|c|c|}
\hline \multirow[b]{2}{*}{ 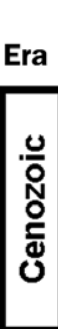 } & $\begin{array}{l}\text { Period } \\
\text { Quaternary }\end{array}$ & \multicolumn{2}{|c|}{$\begin{array}{cc} & \text { Began } \\
\text { Epoch } & \text { (million years ago) }\end{array}$} \\
\hline & Quaternary & $\begin{array}{l}\text { Holocene } \\
\text { Pleistocene } \\
\text { Pliocene } \\
\text { Miocene } \\
\text { Oligocene } \\
\text { Eocene } \\
\text { Paleocene }\end{array}$ & $\begin{array}{l}.01 \\
1.8 \\
5.3 \\
23 \\
34 \\
54 \\
65\end{array}$ \\
\hline \multirow{3}{*}{ 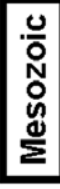 } & Cretaceous & & 145 \\
\hline & Jurassic & & 200 \\
\hline & Triassic & & 251 \\
\hline \multirow{6}{*}{ 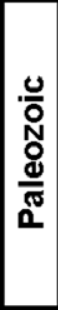 } & Permian & & 299 \\
\hline & Carboniferous & & 359 \\
\hline & Devonian & & 416 \\
\hline & Silurian & & 443 \\
\hline & Ordivician & & 488 \\
\hline & Cambrian & & 542 \\
\hline
\end{tabular}

Figure 2. Geological timescale based on the 2004 timescale endorsed by the International Commission on Stratigraphy.

late Devonian to the late Carboniferous (figure 3). The peak of approximately $31 \%$ atmospheric oxygen during the Carboniferous (Berner 2006), compared with the current $21 \%$, would have greatly facilitated combustion, even if moisture levels were high. The major fall in atmospheric oxygen levels during the Permian and the Triassic may explain the scant evidence for fires, as inferred from the few charcoal deposits found for this period. Nevertheless, during the remainder of the Mesozoic (Jurassic and Cretaceous periods), fires were increasingly important (Scott 2000).

Several lessons are evident from the Paleozoic and Mesozoic history of fire on Earth. First, some of the same fire regimes evident today were present in early land plant communities. For example, understory surface fire regimes, similar to those in many Northern Hemisphere coniferous forests, are indicated by Devonian (395 mya) progymnosperm forests that persisted through frequent fires fueled by shrubs desiccated during dry seasons (Cressler 2001). Similarly, the Carboniferous (345 mya) laminated deposits record fire intervals of 3 to 35 years in progymnosperm communities (Beerling et al. 1998, Falcon-Lang 2000); and in Jurassic (195 mya) gymnosperm forests with tree-ring patterns, charred fragments provide evidence of high-frequency, light surface fires (Francis 1984). These descriptions are similar to historical fire patterns in some western North American pine forests (Allen et al. 2002).

In contrast, the wetland lepidodendron forests of the Carboniferous (345 mya) showed evidence of fire intervals of 105 to 1585 years, with charred apices indicating crown fires (Falcon-Lang 2000). Equivalent crown fires today are common in high-latitude conifer forests and temperate shrublands (Keeley et al. 1999, Johnson et al. 2001). When we consider the changes in oxygen levels and the reshuffling of plant communities, there is every reason to believe that variations in these fire regimes were evident through time, as is the case today.

We can define the necessary ecological conditions for wildland fires, as they involve four specific parameters (figure 1b). In addition to biomass fuels to spread a fire, there must be a dry season that converts potential fuels to available fuels. Such seasonal climates may or may not be annual and may arise from different synoptic weather conditions. The Carboniferous fires in progymnosperm communities that Falcon-Lang (2000) reported were under a monsoonal climate, whereas the Jurassic gymnosperm forests with light surface fires reported by Francis (1984) had tree-ring patterns indicative of a mediterranean climate-mild winter rain and summer drought. Thus, it would appear that fire regimes throughout history have been possible under a range of climatic conditions not unlike today's. However, in addition to seasonality, understanding the ecosystem distribution of fire requires consideration of an additional parameter-fuel structure (figure 1b) —one that forms the basis for different fire regimes, such as the surface fire and crown-fire regimes mentioned above (figure 4). 


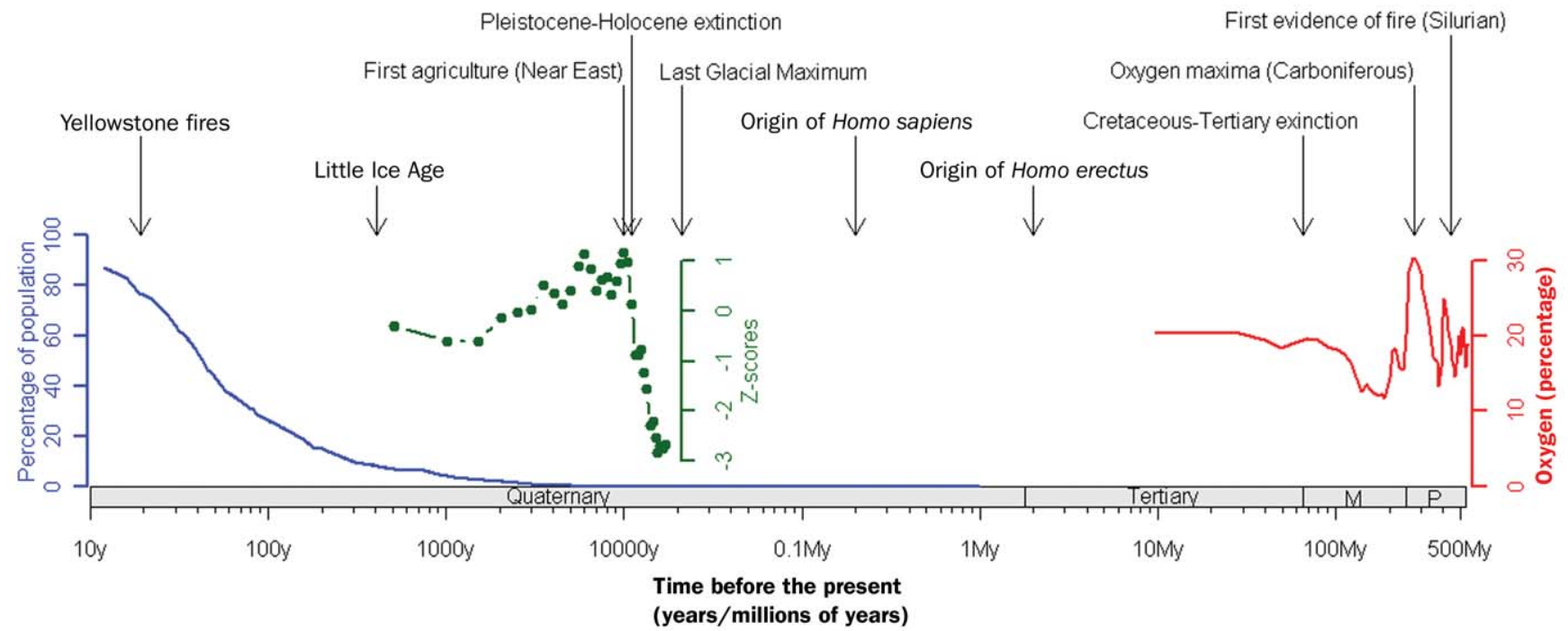

Figure 3. Temporal position of key moments in the history of life (time in logarithmic scale). The blue line denotes the proportion of the human world population relative to 2006 (left y-axis). The red line is the atmospheric oxygen concentration (percentage; right y-axis) from 10 million to 550 million years BP (data taken from Berner 2006). Green dots are the standardized global charcoal values ( $Z$ scores) averaged at 500-year intervals (standardization over the interval 4000 to 100 years BP; data are taken from Power et al. 2008), which indicates changes in the fire regime from 170,000 to 500 years BP. Abbreviations: BP, before the present; M, Mesozoic; P, Paleozoic.

Although the history of fire appears to have been continuous since plants invaded land, evidence that fire has actually altered the biogeography of landscapes and had major impacts on ecosystem function may be tied to the late Tertiary. Indeed, the dramatic rise in charcoal deposition in marine sediments (Herring 1985, Jia et al. 2003) is often cited as evidence of the first rise in fire as an important ecosystem process. It has been postulated that the spread of $\mathrm{C}_{4}$ grasses during the more seasonal climate of the late Tertiary was due to this increase in fire activity, which opened up woodlands and created environments favorable to $\mathrm{C}_{4}$ grasslands (Keeley and Rundel 2005). Although other factors, such as increasing aridity, have been invoked to explain this expansion of $\mathrm{C}_{4}$ grasslands, only fire can account for the fact that expansion was possible because these grasses shifted their distribution to more mesic environments. The high flammability of $\mathrm{C}_{4}$ grasses would have produced a feedback process that further increased fire activity, thus maintaining the grasslanddominated landscape, a process similar to the one currently maintaining many of our savannas. The significant increase in charred grass cuticle and pollen abundant during the same period (Morley and Richards 1993) reinforces this view.

This more modern view of plant evolution is a switch from the long history of paleoecology that viewed changes as being tied solely to climate and soils. This new perspective invites renewed speculation on the origin of plant traits. Resprouting after fire is a widespread trait in all fire-prone environments and in all dicotyledonous plant lineages. Because of the common belief that fire was a novel phenomenon (e.g., Axelrod 1989), resprouting has consistently been viewed as an exaptation (a trait currently of adaptive value that was selected by some other factor) that evolved in response to
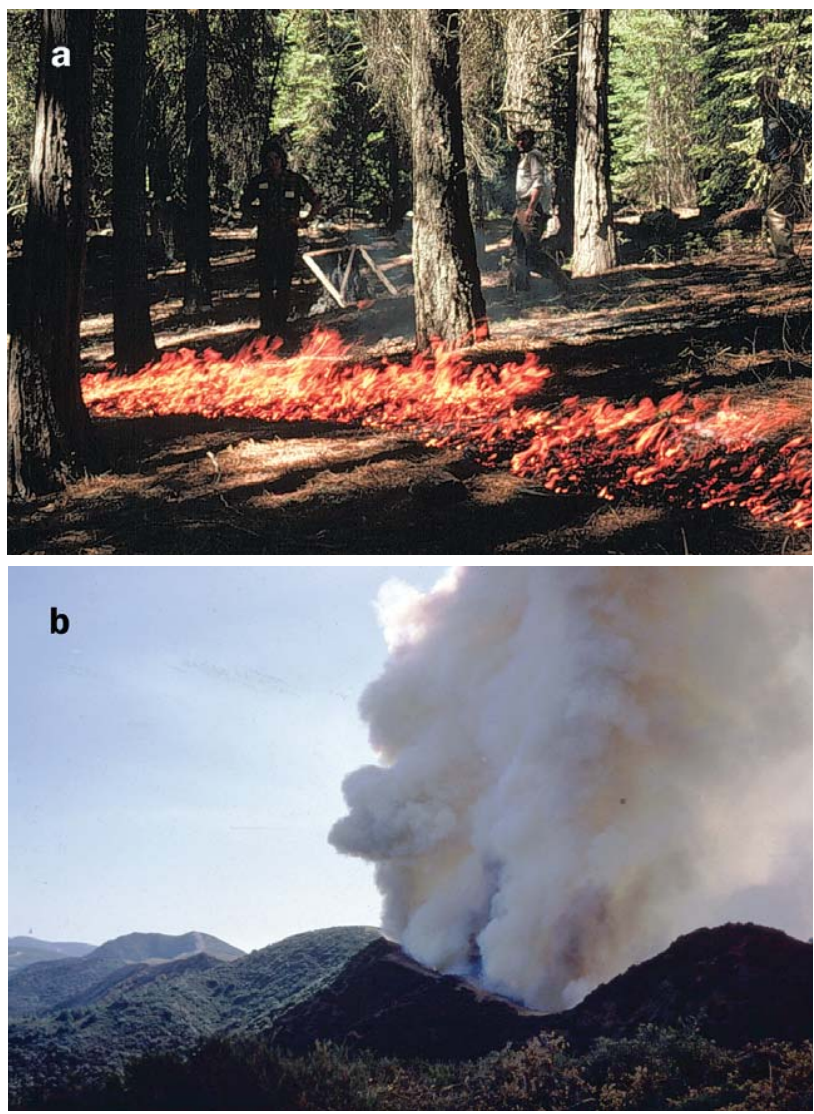

Figure 4. Examples of different fire regimes. (a) Surface fire burning in the understory of a mixed conifer forest in the Sierra Nevada, California. (b) Crown fire in chaparral shrublands, southern California. Photographs: (a) US National Park Service; (b) US Forest Service. 
many types of disturbance. The well-developed story of the early fire presence on Earth suggests new lines of research pointing toward resprouting as an adaptation selected for in response to fire.

The widespread taxonomical distribution of resprouting ability and its presence in old lineages (such as in the gymnosperms Ephedra, Ginkgo biloba, and Wollemia nobilis) suggest that it is an ancient trait in woody land plants, although potentially more recent in some lineages. One example in which fire has most likely played a selective role in the evolution of sprouting is in Northern Hemisphere gymnosperms; most lack any capacity for resprouting, as would be predicted judging from their occurrence in forests typically subjected to low-intensity surface fires, which most mature trees survive. However, of the few gymnosperms that do resprout, all are components of crown-fire regimes, in which aboveground mortality is nearly certain (Keeley and Zedler 1998).

Similarly, tree bark has traditionally been viewed as a trait that evolved in response to multiple environmental factors, including heat, cold, and disturbances such as fire. The genus Pinus is an outstanding example in which fire clearly is the driving force for thick bark, as those lineages prominent in climatic extremes such as deserts and timberline have the thinnest bark in the genus; all other pines dominate in fireprone landscapes (Keeley and Zedler 1998). This radiation very likely began in the Cretaceous and continued through the Tertiary (Millar 1998), suggesting fire was an important ecosystem process throughout these periods.

Serotiny of cones and fruits is closely tied to fire in many plant groups (Lamont et al. 1991), although Axelrod (1980) disputed this and argued that at least in pines, it was due to climate. However, phylogenetic analysis in pines indicates fire has selected for correlated traits that enhance fitness of trees in crown-fire regimes (Schwilk and Ackerly 2001). Charred remains of presumed serotinous cones have been described from early Cretaceous wildfires, as well as remains of analogous structures such as highly sclerotic fern indusia that were dropped when heated by fire (Allen 1998).

Heat shock, chemicals in smoke, and charred wood are signals that trigger germination in seeds from fire-prone environments. These are adaptive in that they enhance fitness by cuing germination to postfire conditions when light, water, and nutrient resources are abundant (Keeley and Fotheringham 2000, Pausas and Verdú 2005). Heat shock is not a cue specific to fire, as soil heating may also trigger germination of these same species on unburned sites with open, bare mineral soil. Smoke, on the other hand, appears to be a highly specific germination cue, and is indicative of a rather specific fire adaptation. Smoke-stimulated germination in species from non-fire-prone ecosystems has been cited as contrary evidence (Pierce et al. 1995), but this conclusion does not consider the fact that smoke is a complex mixture of thousands of chemicals, many of which occur in diverse ecological settings and stimulate many plant processes (Keeley and Fotheringham 2000).
Smoke-stimulated germination is widespread in the phylogeny of angiosperms (figure 5) and occurs in distant areas such as South Africa, Australia, California, and the Mediterranean basin; consequently it has been invoked as an example of convergent evolution that has arisen multiple times in different lineages (Keeley and Bond 1997). On the basis of other examples of physiological convergence such as $\mathrm{C}_{4}$ photosynthesis with a variety of different biochemical pathways in different lineages, this model would predict that unrelated species would evolve mechanisms that are triggered by different components in smoke, and there is some support for that idea (Keeley and Fotheringham 2000). In contrast, Flematti and colleagues (2004) contend that a single organic molecule in smoke is responsible for triggering germination, and this compound is effective in a vast array of plants from fire-prone and non-fire-prone environments. It has been suggested that smoke-stimulated germination represents a single mechanism in primary metabolism and is universal to all smoke-stimulated plants (Kingsley Dixon, Kings Park and Botanic Garden, Perth, Australia, personal communication, 22 February 2009). These alternative hypotheses invite tests that could provide insight into the evolution of this very specific fire adaptation.

\section{The human era: Fire in the preindustrial world}

Early hominids (genus Homo) appeared in eastern Africa about 2.5 mya, and fire has been closely integrated into many stages of their evolution. It is believed that the rise of Homo

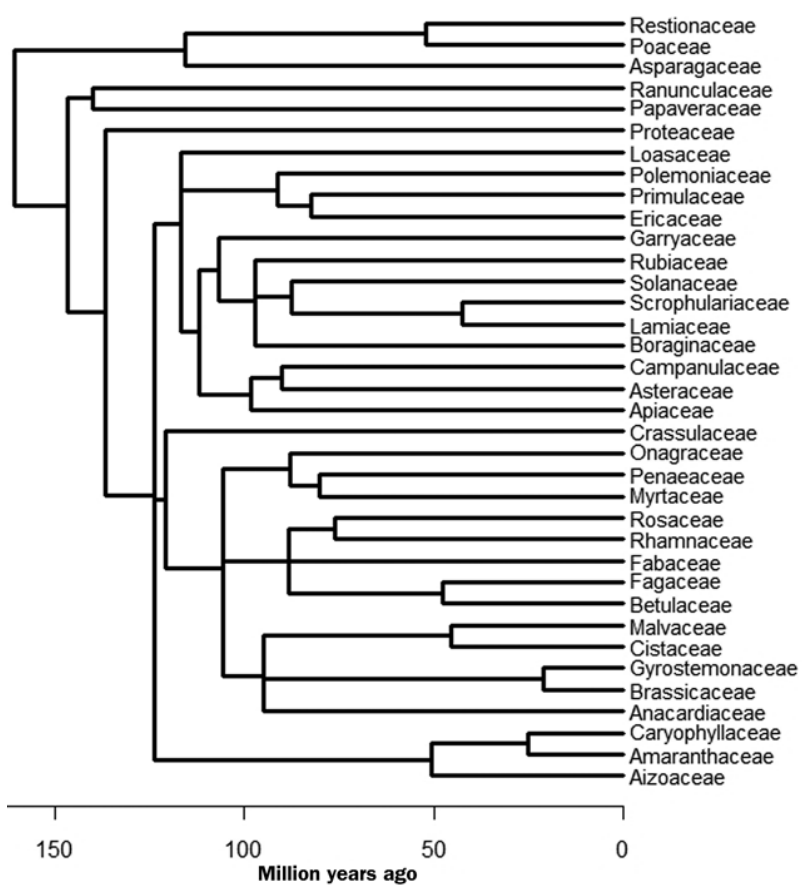

Figure 5. Phylogenetic tree of families with species that have shown smoke-stimulated germination, showing that this trait is phylogenetically widespread. Phylogenetic relatedness data are taken from APG (2003). 
erectus from its more primitive ancestors was fueled by the ability to cook - that is, to use fire (Wrangham et al. 1999). Indeed, recent studies demonstrate a preference by nonhuman primates for cooked food (Wobber et al. 2008). The higher food energy that cooking supplies, as well as the detoxifying effects of heating (which increased the diversity of available food), contributed to a fitness advantage in these early humans. Furthermore, cooking implied a delay in food consumption, which required the development of social abilities for the distribution of tasks within the group (e.g., collection, accumulation, cooking, defense, even stealing), as well as the socializing effect of gathering around nighttime campfires (Pyne 1995). These factors are thought to have prompted the evolution of large brains and bodies, small teeth, modern limb proportions, and other human traits, including many social aspects of human-associated behavior (Wrangham et al. 1999). Indeed, by softening food, fire could have had a large effect on extending the human life span beyond the age of good-quality teeth. This may have been very significant in social organization, including the "grandmother" hypothesis relating child care with social development and human evolution (Hawkes 2004).

These early hominids spread out of Africa, distributing their available fire technology; indeed, fire promoted the dispersal of humans by allowing them to colonize colder environments and by protecting them from predators. There is evidence of the controlled use of fire by Homo erectus in Africa (clusters of ancient hearths) during the Lower Pleistocene (James 1989), about 1.5 mya. The earliest noncontroversial evidence out of Africa is from the Near East during the EarlyMiddle Pleistocene (0.79 mya; Goren-Inbar et al. 2004). The detailed analysis of this archeological site from the Near East demonstrates that fire was used throughout the occupational sequence (about 100,000 years), suggesting that the knowledge these hominids had of fire making enabled them to set fire at will and in diverse environmental settings (Alperson 2008).

During the Paleolithic and Mesolithic ages, fire was used extensively for what has been termed "fire-stick farming" (Bird et al. 2008). This term implies using fire for a variety of reasons: clearing ground for human habitats, facilitating travel, killing vermin, hunting, regenerating plant food sources for both humans and livestock, and even warfare among tribes. These land-management practices had profound impacts not only on fire regimes but also on the landscape vegetation pattern and biodiversity. Commonly, woody, closed-canopy shrublands and woodlands were opened up or entirely displaced by fast-growing annual species that provided greater seed resources, travel, and hunting and planting opportunities. These changes also had cascading effects on ecosystem function. For instance, fire-stick farming by Australian Aborigines created fine-grained landscape mosaics with greater small-animal diversity and increased hunting productivity (Bird et al. 2008). In mediterranean-climate California, where agriculture failed to develop until European colonization, use of fire was extensive and is thought to have created a disequilibrium that contributed to rapid alien plant colonization when Europeans arrived (Keeley 2002). This reshaping of landscapes has posed problems for ecologists trying to understand contemporary landscape patterns.

The spread of humans, perhaps concomitant with climatic changes, contributed to the mass disappearance of megafauna such as mammoths and other large herbivores (i.e., the Pleistocene-Holocene extinction; Burney and Flannery 2005); this extinction would also have resulted in fuel buildup and the consequent change in fire activity, as suggested by the contemporary effects of megaherbivores. In fact, fire-stick farming was probably necessary after the megafauna extinction, not only to open up closed-canopy woodlands to create habitable environments but also to reduce catastrophic fires that would pose a risk to humans (Burney and Flannery 2005), and to increase seed resources needed as humans were forced to switch to a less meat-dependent diet. Although massive wildfires caused by an extraterrestrial impact have been hypothesized to have played a key role in the late Pleistocene megafauna demise in North America (Firestone et al. 2007), this view has been disputed by Pinter and Ishman (2008), who contend that human involvement is a much more likely source of massive fires at this time.

The Neolithic agricultural revolution required fire to alter the natural vegetation from perennial-dominated to annualdominated landscapes. It has been postulated that people preferred to live in fire-prone places because the burning provided them advantages for hunting, foraging, cultivating, and livestock herding (Pyne 1995). Even today, many agricultural and forestry techniques require fire (e.g., slash-andburn agriculture). Charcoal evidence suggests monotonic increases of biomass burning from the last glacial maximum (about 21,000 years BP) up to the start of the agricultural stage (about 10,000 year BP; figure 3), and this trend is linked to climatic warming and the expansion of terrestrial vegetation as a result of the waning of ice sheets (Power et al. 2008). This upward tendency in global fire activity was halted with the rise of agriculture, although a marked regional variation in charcoal accumulation has been observed for this period. With increasing human population throughout history, agriculture has expanded and modified many landscapes. During the latter part of human history, growing populations have tended to limit fuels on many landscapes and to disrupt fuel continuity because of the effects of the combination of agriculture and livestock farming.

The increase in human populations concomitant with the Holocene drying has raised a debate about whether major modifications to vegetation in the last 6000 to 7000 years are more the result of human activities than they are of climatic changes. Similarly, it is often difficult to distinguish between ignitions arising from humans versus natural lighting sources in Holocene fire-regime changes. How landscapes might have looked without any human impact is very difficult, if not impossible, to know, because human presence on the landscape predates contemporary vegetation and climate; the rise in human civilization occurred simultaneously 
with Holocene warming, and both climate-driven and humandriven changes have shaped our current landscape.

At the global scale, both climatic and anthropogenic factors are needed to explain variations in global biomass burning over the last two millennia (Marlon et al. 2008). The decline in charcoal sediment from $1 \mathrm{AD}$ to approximately $1750 \mathrm{AD}$ is attributed to global cooling, with its lowest biomass burning during the Little Ice Age (1400-1800 $\mathrm{AD})$, plus the increased land area dedicated to agriculture; however, the sharp increase afterward can be explained only by exponential increases in world population growth and ignitions (Marlon et al. 2008).

Temporal scales also alter the relative importance of human versus climatic effects on fire regimes. For example, population density and fire are related in pre-Columbian American societies (table 1; Delcourt and Delcourt 1997, Keeley 2002), and in the last 500 years, in Patagonia, climatic influences of fire regime are significant on a short-term basis (annual variability), but the role of humans emerges when examined over decades and centuries (Veblen et al. 1999). What is clear is that humans have affected fire regimes for millennia, and changes in human societies (e.g., from native to Europeans, from preindustrial to postindustrial, etc.) signify changes in fire regimes. Indeed, in temperate ecosystems, there are clear and consistent fire-regime changes as hunting and gathering societies move to agricultural-grazing societies and then to industrial societies (table 1), although these changes may have occurred at different times in different parts of the world (Covington and Moore 1994, Allen et al. 2002, Guyette et al. 2002, Keeley 2002, Pausas 2004, Nowacki and Abrams 2008).

\section{The modern world: An era of rapid alterations in fire regimes}

While humans have altered fire regimes since their early history, recent decades have been marked by rapid-fire regime changes as a result of significant shifts in human population, particularly with respect to growth, socioeconomic factors, and land management. The rate of these changes is probably unprecedented in history, regardless of the direction, and future global change will very likely include further fireregime changes. At a global scale, the direction and the root causes of these changes exhibit extraordinary diversity and require a regional approach to the fire problem.

During the 20th century, fire regimes in temperate latitudes changed in diverse ways related to both ecosystem characteristics and changes in land use. In Mediterranean Europe, industrialization led to people's movement from rural settings into industrial centers, and thus the sudden abandonment of farms and a concomitant reduction in livestock grazing pressure (without replacement by natural grazers). This shift in land use, coupled with growth of tree plantations (mainly dense coniferous stands), has greatly increased fuel buildup, resulting in anomalously large, catastrophic wildfires, as reflected in the great increase in the last few decades in the amount of area burnt annually (Pausas 2004). Over the same period, western US forests have also experienced an increase in hazardous fuels as a result of a highly effective firesuppression policy that excluded fires for much of the 20th century. This "success," coupled with questionable logging practices, has caused unusually high fuel accumulation. Historic high-frequency, low-severity surface fire regimes are now being replaced with low-frequency, high-intensity crown fires that are outside the historical range of variability for these ecosystems. In contrast, in the eastern United States, fire suppression has shifted oak and pine woodlands to mesophytic hardwoods, consequently reducing flammability and fire activity (Nowacki and Abrams 2008).

At the same time, in Europe, North America, Australia, and elsewhere, urban areas have steadily expanded into wildland areas, producing more ignition sources (arson and accidental) and exposing more people to wildfires. Where populations have expanded into naturally high-intensity crown fire ecosystems, such as in many mediterranean-climate regions, the result has often been catastrophic. Witness, for example, the recent loss of human lives and property in Greece, California, Chile, and Australia.

\begin{tabular}{|c|c|c|c|}
\hline Factor & Ignition dependent & Fuel limited & Fuel driven \\
\hline Socioeconomic framework & Hunting and gathering & $\begin{array}{l}\text { Agriculture, grazing, logging } \\
\text { (fragmentation) }\end{array}$ & $\begin{array}{l}\text { Industrialization, fire suppression, } \\
\text { forest recreation values }\end{array}$ \\
\hline Ignitions (related to population) & Low & Moderate & High \\
\hline Fuels (relative amount) & Moderate & Low & High \\
\hline Landscape connectivity & High & Low & Moderate \\
\hline Fire interval & Intermediate & Short/intermediate & Long \\
\hline Fire intensity & Moderate & Low & High \\
\hline Fire size & Intermediate & Small & Large \\
\hline Fuel consumers & Wildlife, fires & Grazers, agriculture & Fires \\
\hline Period (Guyette et al. 2002) & $<1850$ & $1850-1940$ & 1940-1990 \\
\hline
\end{tabular}

Note: These changes occurred in many places (mainly in temperate ecosystems), although in different periods; variation from this general model also occurs because of specific socioeconomic changes.

Source: Generalized from Guyette et al. (2002). 
Population expansion into these fire-prone, crown-fire ecosystems has also had highly undesirable impacts on natural resources. Particularly hard hit are shrublands in western North America, which although managed by fire suppression policies, have experienced more frequent fire, partly because of more human ignitions (Knapp 1998, Keeley et al. 1999). These ecosystems are sensitive to short firereturn intervals and have undergone type conversion from native shrublands to annual grasslands. This has occurred over massive parts of the Great Basin, which are now dominated by invasive cheatgrass (Bromus tectorum), as well as in California, where large parts of the landscape are now dominated by a diverse collection of alien annual grasses and forbs (Keeley 2006). The anthropogenic impact of replacing native woody vegetation with alien herbaceous species has destabilized these ecosystems in a multitude of ways. These changes may reduce habitat for native fauna, extend the length of the fire season, alter functional plant types from deep-rooted shrubs to shallow-rooted grasses that affect watershed stability, and decrease carbon storage potential.

In many tropical broad-leaved forests, fires have been largely absent since the last glacial maximum (Bush et al. 2004). Humans have found, however, that by opening canopies and allowing surface fuels to dry, they can exploit fire for deforestation. Although deforestation expands the agricultural and forestry potential (Cochrane et al. 1999) of an area, it also affects carbon budgets (Mouillot and Field 2005). These land-management practices and the extreme droughts associated with periodic El Niño Southern Oscillation events have led to a massive loss of forested areas, as the substantial losses after the 1997 fires in Indonesia illustrate. The Indonesian fires clearly placed wildfires in a global context: during the burning, the growth rate of carbon dioxide emitted into the atmosphere doubled and reached the highest levels on record; carbon emissions from these fires made up $13 \%$ to $40 \%$ of global mean annual emissions from fossil fuels, yet they came from a relatively small area of the world (Page et al. 2002). It is worth noting that this large amount of carbon came not just from burning trees but also from burning peat. Although deep peat layers are abundant in the region, they generally fail to burn, but because of land-use changes - in this case, drainage for land development or agriculture-these peats were converted into available fuels. The effects of these large wildfires on biodiversity and other natural resources are yet to be fully assessed.

The massive fire in 1988 in Yellowstone National Park-the world's first national park-marked an important landmark in recent fire history. The fire lasted longer than three months and consumed more than 1,400,000 hectares (Wallace 2004). Despite the large investment in fire-suppression activities (\$120 million, 25,000 firefighters), the Yellowstone fire was extinguished only when snow began to fall in mid-September. One widely shared conclusion is that the Yellowstone fire was a natural event, one that occurs at a rotation interval of 200 to 300 years in these crown-fire ecosystems. These forests are resilient to such fires, and within the first decade after the fire, plant and animal communities were well on their way to their prefire composition (Wallace 2004). Tree-ring evidence and pollen and charcoal accumulations over millennia suggest that in many places such massive fires occurred naturally throughout the Holocene (Romme and Despain 1989, Millspaugh et al. 2000). Thus, despite a history of intensive management for fire suppression, this landscape appears to be one of few ecosystems that is still operating within its historical fire regime, a conclusion drawn for related crown-fire forests in the New World boreal zone (Johnson et al. 2001).

The fire in Yellowstone was perhaps the first fire broadcast around the world in the media. It was preceded by another emblematic fire, the Ash Wednesday bushfire, which burned about 500,000 hectares in southeastern Australia in 1983. These events put the issue of wildfires in the minds of many scientists and land managers worldwide. In response to these events, fire science has been placed on an upward trajectory (figure 6) leading to substantial changes in our understanding of fire as a natural ecosystem process (Bond and Keeley 2005). These studies have shown that humans have left a wide footprint on natural fire regimes in all corners of the globe.

\section{The future: Living with wildfires}

A world without fires is like a sphere without roundness - that is, we cannot imagine it. Wildfires have shaped our world since long before humans emerged. We cannot understand our biota, in terms of adaptations and ecosystem distribution, without including fire as a process in the natural history of our planet. During most of Earth's history, fire has been integral to the evolution of flora and fauna, and responsive through

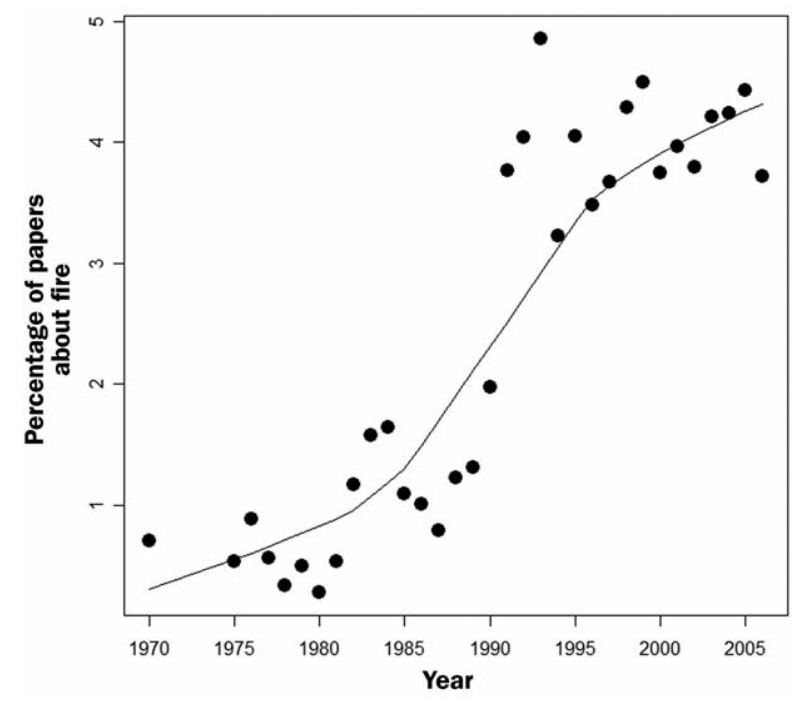

Figure 6. Proportion of scientific papers related to fire published in ecology journals from 1970 to 2006 (Source: ISI Web of Knowledge; www.isiwebofknowledge.com). The International Journal of Wildland Fire was not included to avoid magnifying temporal changes, as this journal started in 1991. The line represents a nonparametric smoothing. 
feedback processes to changes in climate and paleoatmospheric variations.

Humans have had profound impacts on fire regimes, largely by increasing fire frequency and its destructiveness to ecosystems. Although humans have adapted fire for their own use, fire often becomes more destructive than intended, and there is a profound need for both better human understanding of fire relationships and a sound balance between land-management needs and the sustainability of natural ecosystems. One hard lesson is that although there is wide appreciation of the long evolutionary history of fire in many ecosystems, it cannot be assumed that the components of these systems are adapted to all ranges of fire activity. In other words, no species is fire adapted; rather, species are adapted to a particular fire regime, and departures from that regime can have devastating impacts on the sustainability of many ecosystem components.

A pressing question is whether we are prepared to manage fire regimes to suit present and future social demands. Particularly critical is learning how to manage wildland fires in a way that reduces fire hazards to human population centers and at the same time allows the sustainability of resources important for the native biota and watershed stability. Balancing these goals is more challenging for some ecosystems than for others. The western US conifer forests are a prime example of where management practices (frequent prescription burning) are compatible with both reducing fire hazards and protecting resources, and this generalization may apply to all ecosystems that have evolved under a fire regime of frequent, low-intensity surface fires. In contrast, in crown-fire shrublands in such disparate parts of the world as South Australia, southern California, and the Mediterranean basin, accomplishing these goals is far more difficult because management practices that succeed at reducing fire hazard are often destructive to natural resources, in particular, the sustainability of biodiversity (Bradstock et al. 1998, Keeley 2006).

Adding to future uncertainty is the interaction between fires and anthropogenically induced climate change. Climate warming, with its potential for increasing the frequency of extreme droughts, may facilitate the spread of fires. However, warming may also reduce fire activity as higher temperatures may increase or decrease fuels, depending on processes such as decomposition, and alter fuel continuity in very different ways in different ecosystems (Pausas and Bradstock 2007). Present projections of the future impacts of climate change on fire activity often focus on one attribute of the system, such as fuel condition. As global-change studies expand their scope beyond just climate, we will see fire regimes within the context of a multivariate environment and learn more about how they interact with a multitude of ecosystem processes.

\section{Acknowledgments}

This work has been partially financed by the Spanish projects PERSIST (CGL2006-07126/BOS) and GRACCIE (SCD200700067, Consolider-Ingenio 2010, CEAM). Centro de Inves- tigación sobre Desertificación is financed by Consejo Superior de Investigaciones Científicas, the University of Valencia, and Generalitat Valenciana. We thank the reviewers for their insights. This research was part of the US Geological Survey Multi-hazards Demonstration Project. Any use of trade, product, or firm names in this publication is for descriptive purposes only and does not imply endorsement by the US government.

\section{References cited}

Allen CD, Savage M, Falk DA, Suckling KF, Swetnam TW, Schulke T, Stacey PB, Morgan P, Hoffman M, Klingel JT. 2002. Ecological restoration of southwestern ponderosa pine ecosystems: A broad perspective. Ecological Applications 12: 1418-1433.

Allen P. 1998. Purbeck-Wealden (early Cretaceous) climates. Proceedings of the Geologists' Association 109: 197-236.

Alperson N. 2008. Continual fire-making by hominids at Gesher Benot Ya'aqov, Israel. Quaternary Science Review 27: 1733-1739.

[APG] Angiosperm Phylogeny Group. 2003. An update of the Angiosperm Phylogeny Group classification for the orders and families of flowering plants: APG II. Botanical Journal of the Linnean Society 141: 399-436.

Axelrod DI. 1980. History of the maritime closed-cone pines, Alta and Baja California. University of California Publications in Geological Sciences 120: 1-143.

-1989. Age and origin of chaparral. Pages 7-19 in Keeley SC, ed. The California Chaparral: Paradigms Reexamined. Natural History Museum of Los Angeles.

Beerling DJ, Woodward FI, Lomas MR, Wills MA, Quick WP, Valdes PJ. 1998. The influence of Carboniferous palaeoatmospheres on plant function: An experimental modelling assessment. Philosophical Transactions of the Royal Society B 353: 131-140.

Berner RA. 2006. GEOCARBSULF: A combined model for Phanerozoic atmospheric $\mathrm{O}_{2}$ and $\mathrm{CO}_{2}$. Geochimica et Cosmochimica Acta 70: 5653-5664.

Bird RB, Bird DW, Codding BF, Parker CH, Jones JH. 2008. The "fire stick farming" hypothesis: Australian Aboriginal foraging strategies, biodiversity, and anthropogenic fire mosaic. Proceedings of the National Academy of Sciences 105: 14796-14801.

Bond WJ, Keeley JE. 2005. Fire as global 'herbivore': The ecology and evolution of flammable ecosystems. Trends in Ecology and Evolution 20: 387-394.

Bond WJ, Woodward FI, Midgley GF. 2005. The global distribution of ecosystems in a world without fire. New Phytologist 165: 525-538.

Bradstock RA, Bedward M, Kenny BJ, Scott J. 1998. Spatially-explicit simulation of the effect of prescribed burning on fire regimes and plant extinctions in shrublands typical of south-eastern Australia. Biological Conservation 86: 83-95.

Burney DA, Flannery TF. 2005. Fifty millennia of catastrophic extinctions after human contact. Trends in Ecology and Evolution 20: 395-401.

Bush MB, Silman MR, Urrego DH. 2004. 48,000 years of climate and forest change from a biodiversity hotspot. Science 303: 827-829.

Cochrane MA, Alencar A, Schulze MD, Souza CM, Nepstad DC, Lefebvre P, Davidson EA. 1999. Positive feedbacks in the fire dynamic of closed canopy tropical forests. Science 284: 1832-1835.

Covington WW, Moore MM. 1994. Southwestern ponderosa forest structure: Changes since Euro-American settlement. Journal of Forestry 92: 39-47.

Cressler WL. 2001. Evidence of earliest known wildfires. Papaios 16: 171-174.

Delcourt HR, Delcourt PA. 1997. Pre-Columbian Native American use of fire on southern Appalachian landscapes. Conservation Biology 11: 1010-1014.

Falcon-Lang HJ. 2000. Fire ecology in the Carboniferous tropical zone. Palaeogeography, Palaeoclimatology, Palaeoecology 164: 355-371.

Firestone RB, et al. 2007. Evidence for an extraterrestrial impact 12,900 years ago that contributed to the megafaunal extinctions and the Younger 
Dryas cooling. Proceedings of the National Academy of Sciences 104: 16016-16021.

Flematti GR, Ghisalberti EL, Dixon KW, Trengove RD. 2004. A compound from smoke that promotes seed germination. Science 305: 977.

Francis JE. 1984. The seasonal environment of the Purbeck (Upper Jurassic) fossil forests. Palaeogeography, Palaeoclimatology, Palaeoecology 48: 285-307.

Glasspool IJ, Edwards D, Axe L. 2004. Charcoal in the Silurian as evidence for the earliest wildfire. Geology 32: 381-383.

- 2006. Charcoal in the early Devonian: A wildfire-derived KonservatLagerstätte. Review of Palaeobotany and Palynology 142: 131-136.

Goren-Inbar N, Alperson N, Kislev ME, Simchoni O, Melamed Y, Ben-Num A, Werker E. 2004. Evidence of hominin control of fire at Gresher Benot Ya’aqov. Science 304: 725-727.

Guyette RP, Muzika RM, Dey DC. 2002. Dynamics of an anthropogenic fire regime. Ecosystems 5: 472-486.

Hawkes K. 2004. The Grandmother Effect. Nature 428: 128-129.

Herring JR. 1985. Charcoal fluxes into sediments of the North Pacific Ocean: The Cenozoic record of burning. Pages 419-442 in Sundquist ET, Broecker WS, eds. The Carbon Cycle and Atmospheric $\mathrm{CO}_{2}$ : Natural Variations Archean to Present. American Geophysical Union.

James SR. 1989. Hominid use of fire in the Lower and Middle Pleistocene. Current Anthropology 30: 1-26.

Jia G, Peng P, Zhao Q, Jian Z. 2003. Changes in terrestrial ecosystem since 30 Ma in East Asia: Stable isotopes from black carbon in the South China Sea. Geology 31: 1093-1096.

Johnson EA, Miyanishi K, Bridge SRJ. 2001. Wildfire regime in the boreal forest and the idea of suppression and fuel buildup. Conservation Biology 15: 1554-1557.

Keeley JE. 2002. Native American impacts on fire regimes of the California coastal ranges. Journal of Biogeography 29: 303-320.

. 2006. Fire management impacts on invasive plant species in the western United States. Conservation Biology 20: 375-384.

Keeley JE, Bond WJ. 1997. Convergent seed germination in South African fynbos and Californian chaparral. Plant Ecology 133: 153-167.

Keeley JE, Fotheringham CJ. 2000. Role of fire in regeneration from seed. Pages 311-330 in Fenner M, ed. Seeds: The Ecology of Regeneration in Plant Communities. 2nd ed. CAB International.

Keeley JE, Rundel PH. 2005. Fire and the Miocene expansion of $\mathrm{C}_{4}$ grasslands. Ecology Letters 8: 683-690.

Keeley JE, Zedler PH. 1998. Evolution of life histories in Pinus. Pages 219-250 in Richardson DM, ed. Ecology and Biogeography of Pinus. Cambridge University Press.

Keeley JE, Fotheringham CJ, Morais M. 1999. Reexamining fire suppression impacts on brushland fire regimes. Science 284: 1829-1832.

Knapp PA. 1998. Spatio-temporal patterns of large grassland fires in the intermountain West, U.S.A. Global Ecology and Biogeography Letters 7: 259-272.

Lamont BB, Maitre DCL, Cowling RM, Enright NJ. 1991. Canopy seed storage in woody plants. Botanical Review 57: 277-317.

Marlon JR, Bartlein JP, Carcaillet C, Gavin DG, Harrison SP, Higuera PE, Joos F, Power MJ, Prentice IC. 2008. Climate and human influences on global biomass burning over the past two millennia. Nature Geoscience 1: 697-702.

Millar CI. 1998. The early evolution of Pinus. Pages 69-91 in Richardson D, ed. Ecology and Biogeography of Pines. Cambridge University Press.

Millspaugh SH, Whitlock C, Bartlein PJ. 2000. Variations in fire frequency and climate over the past 17,000 years in central Yellowstone National Park. Geology 28: 211-214.
Morley RJ, Richards K. 1993. Graminieae cuticle: A key indicator of Late Cenozoic climatic change in the Niger Delta. Review of Palaeobotany and Palynology 77: 119-127.

Mouillot F, Field CB. 2005. Fire history and the global carbon budget: A $1^{\circ}$ $\times 1^{\circ}$ fire history reconstruction for the 20th century. Global Change Biology 11: 398-420.

Nowacki GJ, Abrams MD. 2008. The demise of fire and "mesophication" of forests in the eastern United States. BioScience 58: 123-138.

Page SE, Siegert F, Rieley JO, Boehm H-DV, Jaya A, Limin S. 2002. The amount of carbon released from peat and forest fires in Indonesia during 1997. Nature 420: 61-65.

Pausas JG. 2004. Changes in fire and climate in the eastern Iberian Peninsula (Mediterranean basin). Climatic Change 63: 337-350.

Pausas JG, Bradstock RA. 2007. Fire persistence traits of plants along a productivity and disturbance gradient in mediterranean shrublands of SE Australia. Global Ecology and Biogeography 16: 330-340.

Pausas JG, Verdú M. 2005. Plant persistence traits in fire-prone ecosystems of the Mediterranean basin: A phylogenetic approach. Oikos 109: 196-202.

Pierce SM, Esler K, Cowling RM. 1995. Smoke-induced germination of succulents from fire-prone and fire-free habitats in South Africa. Oecologia 102: 520-522.

Pinter N, Ishman SE. 2008. Impacts, mega-tsunami, and other extraordinary claims. GSA Today 18: 37-38.

Power JJ, et al. 2008. Changes in fire regimes since the Last Glacial Maximum: An assessment based on a global synthesis and analysis of charcoal data. Climate Dynamics 30: 887-907.

Pyne SJ. 1995. World Fire: The Culture of Fire on Earth. Henry Holt.

Romme WH, Despain DG. 1989. Historical perspective on the Yellowstone fires of 1988. BioScience 39: 695-699.

Schwilk DW, Ackerly DD. 2001. Flammability and serotiny as strategies: Correlated evolution in pines. Oikos 94: 326-336.

Scott AC. 2000. Pre-Quaternary history of fire. Palaeogeography, Palaeoclimatology, Palaeoecology 164: 297-345.

Scott AC, Glasspool IJ. 2006. The diversification of Paleozoic fire systems and fluctuations in atmospheric oxygen concentration. Proceedings of the National Academy of Sciences 103: 10861-10865.

Veblen TT, Kitzberger T, Villalba R, Donnegan J. 1999. Fire history in northern Patagonia: The roles of humans and climatic variation. Ecological Monographs 69: 47-67.

Wallace LL, ed. 2004. After the Fires: The Ecology of Change in Yellowstone National Park. Yale University Press.

Wobber V, Hare B, Wrangham R. 2008. Great apes prefer cooked food. Journal of Human Evolution 55: 340-348.

Wrangham RW, Jones JH, Laden G, Pilbeam D, Conklin-Brittain NL. 1999. The raw and the stolen: Cooking and the ecology of human origins. Current Anthropology 40: 567-590.

Juli G. Pausas (e-mail: juli.g.pausas@uv.es) is a research ecologist at the Centro de Investigación sobre Desertificación of the Spanish National Research Council in Valencia (CIDE, CSIC), Spain. Jon E. Keeley (e-mail: jon_keeley@usgs.gov) is a research ecologistwith the US Geological Survey, Western Ecological Research Center, Sequoia-Kings Canyon Field Station, in Three Rivers, California, and an adjunct full professor at the Department of Ecology and Evolutionary Biology at the University of California, Los Angeles. Both are interested in how fire shapes species, communities, and landscapes. 